\title{
Empowering The Language Learner: Language Learning Strategy Training And Self-Regulation In An EFL Classroom
}

Gabriella Torres, Hankuk University of Foreign Studies, Korea

\begin{abstract}
The purpose of this paper is to illustrate how an understanding of the Good Language Learner models described in the SLA literature can be used to tailor and implement a program of learning strategy training and self-regulatory practices in the classroom to empower L2 learners in an EFL context. The paper begins by reviewing the various definitions and classification systems of language learning strategies prominent in the SLA literature. It then examines the evolution of the "good" language learner by specfically looking at the GLL in terms of what strategies they employ, the manner in which they utilize those strategies and what drives them to be proactive in their learning process. The author concludes by proposing a program of metacogntive strategy training and self-regulatory awareness practices for classroom implementation in order to increase the language learning effectiveness of students in a South Korean university.
\end{abstract}

Keywords: Affective Strategies; Cognitive Strategies; Learning Strategies; Metacognitive Strategies; SelfRegulation; Social Strategies; Strategy Training

\section{INTRODUCTION}

s most teachers of a foreign or second language can attest to, certain students seem to have a natural ability or "knack" for acquiring the target language. This observation has lead researchers to investigate and identify the specific behaviors of "good" language learners and examine the strategies they utilize that facilitate their learning of the L2. By identifying these factors, it is suggested that teachers, through strategy training, will be able to improve the performance of their less successful language learners by giving them the means with which to take control of their learning process and become more self-directed and effective learners (Chamot 2005; Oxford 1990; Rubin 1975; Tseng et al. 2006).

The purpose of this paper is to first examine the various definitions and taxonomies of language learning strategies as described in the literature. The author will then proceed to identify the different models of a "Good" Language Learner (GLL) to suggest that the construct of the GLL is a viable one. The writer will then use the GLL classifications to examine how this knowledge can lead to creating better, more empowered language learners in a South Korean university EFL context through a proposed focus on metacognitive strategy training and awareness in student self- regulatory practices.

\section{LANGUAGE LEARNING STRATEGIES}

Before proceeding, it is important for the purposes of this paper to first review the various definitions and classification systems of language learning strategies prominent in the SLA literature that the good language learner probably employs. 


\subsection{Definitions}

Brown defines learning strategies as being comprised of the "specific methods of approaching a problem or task, modes of operation for achieving a particular end, [and] planned designs for controlling and manipulating certain information" (2000: 113). According to Chamot (2005), language-learning strategies (LLS) are the procedures that facilitate a language-learning task. O'Malley and Chamot (1990) describe LLS as being "special thoughts or behaviors that individuals use to help them comprehend, learn, or retain new information" (p. 1).

Though these definitions are useful for establishing the initial framework of a language learning strategy, it is difficult to see what precisely makes an activity, technique or behavior strategic and not merely part of an ordinary learning activity (Dornyei 2005: 164).

This differentiation is somewhat clarified with Bialystock (1985: 258) who adds the caveat of cognizance as a part of her definition of language learning strategies:

...learning strategies are construed as activities undertaken by learners, whether consciously or not, that have the effect of promoting the learner's ability either to analyze the linguistic knowledge relevant to the language under study, or to improve control procedures for selecting and applying that knowledge under specific contextual conditions.

Oxford also uses cognizance as a defining factor of language learning strategies as she states, "learning strategies are behaviors, techniques, or actions used by students, often consciously, to enhance their learning" (Oxford 1990, cited in Oxford et al. 1990: 197).

However, according to Dornyei (2005: 162), LLS are not attributes of the learner themselves but aspects of the greater learning process. He goes on to cite Cohen's take on learning strategies, which, similarly to the definitions of LLS above, features cognizance as a distinct characteristic. Cohen defines learning strategies as "learning processes which are consciously selected by the learner" (Cohen 1998: 4, cited in Dornyei 2005: 162).

After reviewing these definitions, one can surmise, that LLS include the processes, behaviors, techniques and actions consciously employed (to varying degrees) by L2 learners to facilitate and enhance the effectiveness of their learning.

\section{$2.2 \quad$ Taxonomies}

The following section of this paper will provide a review of the predominant LLS taxonomies found in the SLA literature.

\subsubsection{Oxford}

As Dornyei (2005) states, "learning strategies are immensely ambiguous phenomena and nothing is clearcut about them" (p. 162). In fact, Oxford (2002) notes that researchers have dedicated much time and energy into attempting to define and systematize the wide array of possible learning strategies (p. 127). As per Oxford (2005: 127), these systems can be outlined into the following five distinct categories:

- Systems related to behaviors of successful language learners

- $\quad$ Systems based on psychological functions, such as cognitive, metacognitive and affective

- $\quad$ Linguistically based strategy systems dealing with inference, language monitoring, formal rule practicing, and functional (communicative) practicing

- $\quad$ Systems based on particular language skills such as oral production, vocabulary learning, reading comprehension, or writing

- $\quad$ Systems based on different types (or styles) of learners 
Though these systems are helpful in identifying these distinct categories and representing more than two dozen strategy systems, it also indicates a potential major problem in the area of L2 strategy research, which is the "lack of a coherent, widely accepted system for describing strategies" (Oxford 2002: 128).

To make a more coherent and comprehensive typology, Oxford (2002: 128) developed a strategy system (based on the theory that the learner is a "whole person"), which is made up of six sets of L2 learning behaviors. The system is comprised of the following strategy groups:

- $\quad$ Affective: anxiety reduction through laughter and meditation, self-encouragement through affirmations and self-reward through praise and tangible reinforcement.

- $\quad$ Social: asking questions, cooperating with native speakers of the language and becoming culturally aware.

- Metacognitive: paying attention, consciously searching for practice opportunities, planning for language tasks, self-evaluating progress and monitoring errors.

- $\quad$ Memory-related: grouping, imagery, rhyming, moving physically, and structured reviewing.

- $\quad$ General cognitive: reasoning, analyzing, summarizing, and practicing.

- $\quad$ Compensatory (to make up for limited knowledge): guessing meanings from the context and using synonyms and gestures to convey meaning.

\subsubsection{O'Malley and Chamot}

In a classification system comparable to Oxford's, O'Malley and Chamot (1990) distinguish the following three language learning strategy groups:

- $\quad$ Cognitive strategies: which refer to the processes and behavior that learners use to help them improve their ability to learn aspects of the language.

- Metacognitive strategies: which refer to the awareness of the mental processes used in the learning process, planning, monitoring, and evaluating learning after it has taken place.

- Social/affective strategies: which includes diverse behaviors such as cooperation, questioning and clarification, self-talk, and seeking out practice opportunities.

\subsubsection{Dornyei}

Dornyei (2005) takes issue with both of the above-mentioned LLS systems for three distinct reasons. With regards to Oxford's taxonomy (see 2.2.1), Dornyei argues that a) compensatory strategies are related to language use as opposed to language learning, and b) memory strategies constitute a subclass of cognitive strategies and should therefore not be treated independently (2005). In the case of O'Malley and Chamot (see 2.2.2), Dornyei sees their social/affective strategies as unrelated to the cognitive theoretical basis outlined by the authors and serves more as a miscellaneous category designed to accommodate strategies that did not fit into the first two types but could not be left out either (2005: 168-169). He therefore proposes a new compounded typology comprised of both taxonomies resulting in the following four main components (Dornyei 2005: 169):

- $\quad$ Cognitive strategies: the manipulation or transformation of the learning materials/input.

- Metacognitive strategies: higher-order strategies aimed at analyzing, monitoring, evaluating, planning and organizing one's own learning process.

- $\quad$ Social strategies: interpersonal behaviors aimed at increasing the amount of L2 communication and practice the learner undertakes.

- $\quad$ Affective strategies: taking control of the emotional (affective) conditions and experiences that shape one's subjective involvement in learning.

\section{THE GOOD LANGUAGE LEARNER}

This portion of the paper will examine the evolution of the "good" language learner in SLA research. Specifically, this section will look at the GLL in terms of what strategies they employ, the manner in which they utilize those strategies and what drives them to be proactive in their learning process. 


\subsection{Early Lists: What the Good Language Learner Does}

Early lists of the good language learner focused on describing what the GLL did that contributed to their success in regards to language learning and acquisition. Rubin's (1975) seminal list, which laid the foundation for much of the subsequent GLL research and literature, outlined seven actions (or strategies), which Rubin believed were integral to successful language learning. According to Rubin, the good language learner engages in the following strategies:

- Willingly and accurately guesses.

- Wants to communicate and learns from that communication.

- Willingly makes and learns from his/her mistakes due to their lack of inhibitions.

- $\quad$ Pays attention to form.

- $\quad$ Practices and seeks out opportunities to use the L2.

- $\quad$ Monitors his/her own speech and that of others.

- $\quad$ Attends to the context of the speech act to attain meaning.

Other early lists added that successful L2 learners also think in the target language and address the affective aspects of language learning (Naiman, Frohlich, \& Todesco 1975, cited in Oxford 2002: 125). The 1978 list of strategies from Naiman's The GLL noted that good adult language learners $a$ ) take an active approach, $b$ ) recognize and exploit the systematic nature of the L2 c) use the L2 for communication and interaction, $d$ ) manage their own affective difficulties with L2 learning, and $e$ ) monitor their language performance (Naiman et al. 1978, cited in Norton \& Toohey 2001).

\subsection{How the Good Language Learner Does It}

The preliminary lists of the late 1970s gave researchers and teachers insight into the actions of the GLL. However, as GLL research developed it became clear that the success of L2 learners was not merely limited to what they did (i.e. their strategies), as all students, whether they are cognizant of it or not (Bialystock 1985), use strategies to a certain degree, but that what made them more successful than their peers was how they used their strategies (Chamot \& Kupper 1989; Chamot 2005). As Chamot notes, "Effective language learners know how to use appropriate strategies to reach their learning goals, whereas ineffective language learners are less expert in their strategy choice and use" (Chamot \& Kupper 1989: 13).

The following table illustrates the difference in strategy utilization between effective/ "good" language learners and less successful L2 learners.

Table 1: Comparison of Strategy Utilization Between GLLs and Ineffective Learners

\begin{tabular}{|l|l|l|}
\hline $\begin{array}{c}\text { Utilization of } \\
\text { Strategy in Terms } \\
\text { of: }\end{array}$ & \multicolumn{1}{|c|}{ Effective/ "Good" L2 Learner } & \multicolumn{1}{|c|}{ Ineffective L2 Learner } \\
\hline Frequency & $\begin{array}{l}\text { Utilize more strategies more often (Chamot \& } \\
\text { Kupper 1989). }\end{array}$ & $\begin{array}{l}\text { Utilize fewer strategies and with less frequency (Chamot \& } \\
\text { Kupper 1989) }\end{array}$ \\
\hline Range \& Variety & $\begin{array}{l}\text { Utilize a greater range and variety of } \\
\text { metacognitive, cognitive, and social-affective } \\
\text { strategies for successful completion of both } \\
\text { receptive and productive task types (Chamot \& } \\
\text { Kupper 1989). }\end{array}$ & $\begin{array}{l}\text { Smaller repertoire of strategy types that do not lead to } \\
\text { successful task completion. (Chamot \& Kupper 1989). }\end{array}$ \\
\hline $\begin{array}{l}\text { Appropriateness/ } \\
\text { Matching }\end{array}$ & $\begin{array}{l}\text { Skilled at matching appropriate strategies to the } \\
\text { task (Chamot 2005; Chamot \& Kupper 1989). }\end{array}$ & $\begin{array}{l}\text { Frequently use inappropriate strategies for the task resulting in } \\
\text { not successfully completing the task. Seemingly lack } \\
\text { metacognitive knowledge about task requirements needed to } \\
\text { select appropriate strategies (Chamot 2005; Chamot \& Kupper } \\
1989) . .\end{array}$ \\
\hline Purposefulness & $\begin{array}{l}\text { More purposeful in their approach to the task } \\
\text { and in strategies used to complete the task } \\
\text { (Chamot \& Kupper 1989). }\end{array}$ & $\begin{array}{l}\text { Strategies are applied in a random way without careful } \\
\text { planning or targeting of strategies to the task (Vann \& } \\
\text { Abraham 1989, cited in Oxford 2002). Strategies are often } \\
\text { used in an unconnected and uncontrolled manner (Ehrman et } \\
\text { al. 2003: 315, cited in Tseng et al. 2006). }\end{array}$ \\
\hline
\end{tabular}




\subsection{The Good Language Learner: Just Do It!}

Recent studies in SLA are now beginning to explore a new facet of the GLL, which examines their proactive nature and self-regulatory capacities.

\subsubsection{Proactive Nature: Seek and Deploy}

As Macaro (2001) concluded about language learners, "One thing seems to be increasingly clear and that is that, across learning contexts, those learners who are proactive in their pursuit of language learning appear to learn best," (Macaro 2001: 264, cited in Dornyei 2005: 190). What some researchers are now taking note of in regards to the GLL is that it is not only what the GLL does that makes them a strategic, or effective, language learner but rather the fact that they put creative effort into trying to improve their own learning (Tseng et al. 2006). In other words, what separates the GLL from their less successful classmates is their proactive approach to their learning: they actively seek out strategies to use in their L2 acquisition and put those strategies into practice to achieve L2 success (Dornyei 2005: 190).

\subsubsection{Self-Regulation: Strategic Fuel}

What, then, makes one learner more proactive than the other? Recently, a move has been made in SLA to understand the "good" language learner in regards to their self-regulatory capacity (Dornyei 2005; Macaro 2001; Tseng et al. 2006). Drawing from the field of educational psychology, SLA researchers have set out to "capture the secret of the effective learners' 'proactiveness' by focusing on the self-regulatory practices and the specific learner capacity underlying it" (Dornyei 2005: 190) as it is this "innate self-regulatory capacity that fuels their efforts to search for and then apply personalized strategic mechanisms" (Tseng et al. 2006: 79) to enhance the effectiveness of their L2 learning process.

According to Dornyei, self-regulation of academic learning, a category under which language learning would fall, is a "multidimensional construct, including cognitive, metacognitive, motivational, behavioral, and environmental processes" (2005: 191). It encompasses the "volitional aspects of self - and task - management...that provide the individual with the capacity to adjust his or her actions and goals to achieve desired results in light of changing environmental conditions" (Snow et al. 2000: 751, cited in Dornyei 2005: 191).

Based on these definitions, we could then say, more specifically, that GLLs engage in the following selfregulatory strategies as outlined by Tseng et al. (2006) to exert control over these five facets of self-regulation:

- $\quad$ They exert commitment control, which helps to preserve and increase the learners' original goal commitment.

- $\quad$ They exert metacognitive control, which involves the monitoring and controlling of concentration and the curtailing of any unnecessary procrastination.

- $\quad$ They exert satiation control, which helps to eliminate boredom and to add extra attraction or interest to the task.

- $\quad$ They exert emotion control, which concerns the management of disruptive emotional states or moods and the generation of emotions that will be conducive to implementing one's intentions.

- $\quad$ They exert environmental control, which helps to eliminate negative environmental influences and exploit positive environmental influences.

\subsection{The Good Language Learner: Final Thoughts}

From examining the GLL characterizations in the above sections, the author feels that there is enough research to suggest that there is indeed such a thing as a "good" language learner. However, our understanding of just what makes a language learner "good" has broadened with the development of research in this area. It is clear that the construct of the GLL has extended over time to "encompass a broad perspective of various integrated and interrelated micro-processes, of which the use of learning strategies is only one" (Dornyei 2005: 192). Perhaps this evolution is best encapsulated by Chamot and Rubin (1994) when they stated that, "the good language learner 
cannot be described in terms of a single set of strategies but rather through the ability to understand and develop a personal set of effective strategies" (p. 372, cited in Tseng et al. 2006: 95).

\section{LANGUAGE LEARNERS IN A SOUTH KOREAN UNIVERSITY}

Before addressing the ways in which knowledge of the GLL can be utilized by teachers to create more effective language learners, the context in which the author proposes to implement any training or awareness must first be established.

\subsection{Department Overview}

I currently teach in the Practical English Department at Hankuk University of Foreign Studies in Yongin, a satellite city of Seoul. The Practical English Department teaches the required core classes of Practical English 1 and 2 to all majors of the university. The department is comprised of ten native English speaking faculty members from the United States, Canada and the United Kingdom, the majority of whom are trained or educated in TEFL/TESL and have 5+ years of experience teaching English as a Foreign Language in university contexts in Asia.

\subsection{Curriculum \& Classroom Overview}

The Practical English curriculum at this institution is communicative in nature with a focus on grammar and form and is taught both in the spring and fall semesters. Each class meets for three hours per week over a course of 16 weeks. With the exception of English majors, these are the only English courses undergraduates are required to take in their university career.

Prior to taking the course, students are given a placement exam. Based on their scores they are placed in beginning, intermediate or advanced classes. Each level has its own textbook which is organized by theme and language focus, though all teachers, regardless of level or textbook, are required to evaluate their students based on quizzes, a midterm exam, a final exam, and two presentations.

Practical English class sizes range anywhere from 10 to 30 students and are made up of a variety of majors, though lower level classes, the level I currently teach, are generally made up of first year students majoring in engineering, math, and science.

\subsection{Limitations}

Within this context there are many limitations for the language learner in terms of achieving L2 proficiency. Firstly, students only meet with their professors three hours per week over a 16-week semester. For many of them, this is the only interaction they may have with an L2 speaker, making opportunities for practice outside of the classroom limited if not non-existent. Additionally, for many first year students, they are unprepared for the type of independent learning that is characteristic of university. As Nunan (2002) notes, students "expect the teacher to structure the learning situation for them, tell them what to learn and how to learn, as their high school teachers have done" (p. 133). This can be a difficult and frustrating obstacle to overcome for students who are unaccustomed to making decisions about their learning process on their own.

\section{INCREASING LL EFFECTIVENESS IN MY CONTEXT}

The following section examines ways in which the author could improve the effectiveness of her current language learners.

\subsection{Language Learning Strategy Training}

As noted by Chamot (2005), "Strategy instruction can contribute to the development of learner mastery and autonomy"(p. 126). This is highlighted by Nunan (2002) who, after conducting an action research study in learner strategy training and self-monitoring at the University of Hong Kong, concluded "language classrooms should have 
a dual focus - not only on teaching language content, but also on developing learning processes" (p.143). This sentiment is further echoed by O'Malley et al. (1985) who state "classroom instruction on learning strategies with integrative language skills can facilitate learning" (p. 577). Therefore, incorporating LLS training in the classroom seems a viable way in which to create more effective learners.

\subsection{Metacognitive Focus}

As noted above, LLS training can have a positive influence on language learners and their L2 learning. Out of all the various strategy groups however, it would seem that metacognitive learning strategies play a particularly important role in effective L2 learning. As asserted by O'Malley and Chamot (1990), "Metacognitive strategies have been considered to be vital for successful learning in SL literature" (cited in Takeuchi 2003: 387), a sentiment also acknowledged by Chamot who notes, "The development of students' metacognition... has been urged by a number of learning strategy researchers" (Anderson 2002; Chamot et al. 1999; National Capital Language Resource Center 2003; Rubin 2001; Wenden 2000; cited in Chamot 2005: 124). It would seem that a metacognitive focus is of particular importance to GLLs in an Asian foreign language context as is expressed by Takeuchi in his study of the Japanese GLL: "Special attention seems to have been paid by GLLs to the use of metacognitive strategies such as 'maximizing opportunities to use the language,' " (2003: 387). Another argument in favor of implementing metacognitive focused LLS training is that many students, especially within an EFL context such as mine, already come equipped with well known and highly used cognitive learning strategies. As noted by Chamot:

Some cognitive learning strategies... are so much a part of what foreign language students may already be doing that the teacher may wish to focus on expanding students' range of strategies rather that than refining wellknown strategies already in use (1989: 20).

She goes on to say that generally students use a much smaller proportion of metacognitive strategies that are mostly limited to planning (Chamot \& Kupper 1989). Therefore, based on these two points, incorporating an LLS instructional program with a distinct focus on metacognitive strategies seems an enterprise worth undertaking in my particular context.

\subsection{Creating Practice Opportunities for Students to Seek Out}

As noted above, one major obstacle for language learners to overcome is finding opportunities for L2 practice, an essential metacognitive strategy (Oxford 2002) actively employed by GLLs in both ESL and EFL contexts (Rubin 1975; Takeuchi 2003). However, as noted above (see 4.3), opportunities to engage in the L2 are often limited making this an almost impossible strategy to employ, particularly when living and studying outside of major metropolitan areas, which is the case for the majority of my students (see 4.1). Therefore, a solution to this problem would be to raise student awareness of websites in which they can actively engage in the L2 skills of listening, reading, speaking, and writing.

The first website worth highlighting to my students is www.TED.com which features talks from prominent academics, artists, philosophers, activists and scientists from around the world covering a wide variety of topics. This website offers students an opportunity to listen to the L2 and engage in discussions online about the talks themselves. A particularly attractive feature of this site is that most of the videos offer subtitles so that students can read the English subtitles as they follow along with the talk. This feature is especially appealing to lower level students of English who want to practice their listening skills and increase their exposure to the L2.

The second website worth noting is www.Podomatic.com. With this website, students are able to record and create podcasts using the L2. Students, with whom I have used this site in the past, cited it in their selfreflections as a useful tool in helping them improve their speaking, specifically in the area of pronunciation. This website also facilitates the monitoring and evaluating of student language production as podcasts can be played back and evaluated by the student. Additionally, students can keep track of their communicative progress throughout the course of the semester. 
The third website deserving of classroom attention is www.proboards.com, a hosting site for forums on the Internet. As I have done with past classes, I create a forum specific to the class and assign regular writing assignments which they must post to the forum. Students are then encouraged to engage in discussions with each other online using the L2 by commenting on posts and giving feedback. This allows students to take a more active role in their learning process. As with Podomatic.com, this website facilitates the monitoring and evaluating of student (written) language production.

The Internet is a valuable resource which can easily be integrated into the classroom and provide L2 practice opportunities for the students that may otherwise be lacking. These three websites can first be brought to the students' attention by incorporating them into lesson plans, homework assignments and projects as Oxford (2002) notes, "Strategy training succeeds best when it is woven into regular class activities on a normal basis, according to most research" (p. 126). I can encourage students to use these sites on their own by explicitly stating how the use of these websites is an effective metacognitive language learning strategy as "both L2 and non-L2 studies have shown that the most effective strategy training is explicit" (Oxford 2002: 126). Another advantage of these sites is the opportunity it provides for students to engage in other metacognitive learning strategies such as monitoring, planning and self-evaluation. These sites allow learners to consciously engage in metacognitive strategies throughout the semester and well after the completion of the course

\subsection{Awareness of Self-Regulatory Capacities}

Lastly, it is important to note that effective learning is not limited to language learning strategies alone. There are other behavioral, motivational and environmental factors (to name a few) that influence the success of the language learner. These factors are encompassed by aspects of self-regulation which, "are not confined to the area of learning but concern other types of cognitive and behavioral processes" (Dornyei 2005: 190). In other words, selfregulation refers to the "self-directive process through which learners transform their mental abilities into taskrelated academic skills" (Zimmerman 2001: 1, cited in Dornyei 2005: 191). Therefore, the greater awareness and understanding a student has in regards to these processes or factors, the more actively they can participate in their individual learning process. Tools such as the SRCvoc, developed by Tseng et al. (2006), are a good point of departure for students to first identify and become familiar with their self-regulatory practices. This could then be paired with guided journaling that could further aid students in monitoring their self-regulatory capacities in regards to the five self-regulatory controls (see 3.3.2).

I agree with Tseng et al. (2006) that setting the self-regulatory process into motion through awareness and understanding is an essential aspect to empowering L2 learners. Furthermore, in an Asian EFL context such as mine, the need for learner empowerment is great (see 4.3). Therefore, self-regulation is a critical component necessary for creating empowered learners, as it is an empowered learner who is a proactive learner, and it is the proactive language learner who learns best (Macaro 2001).

\subsection{Discussion: The Extent of Increasing LL Effectiveness}

It is clear that there are many ways in which teachers can help increase the language learning effectiveness of their students. However, the extent to which language learners can become more effective is difficult to determine as "there is no single means of learning a second language" (Brown 2000: 163) and numerous factors, including motivation and personality factors (Brown 2000) contribute to the overall effectiveness of a learner. Therefore, it seems that a more worthwhile endeavor for teachers to undertake is to utilize their pedagogical tools (Brown 2000) to create active and conscious learners, empowered by the knowledge of their learning process and capable of making proactive and informed contributions to increasing the effectiveness of their own L2 learning (Dornyei 2005).

\section{CONCLUSION}

Having examined the characteristics that comprise our notions of the GLL, I do think that the construct is a viable one. In other words, the "good" language learner does exist. However, I think that what truly defines the effective language learner is the degree to which they are proactive about their learning. 
As any language learner or teacher can attest to, the intricacies and subtleties of a language often take a lifetime to learn. Therefore, instead of focusing on creating "good" language learners, I think our efforts should instead be focused on creating empowered language learners. Through our understanding of the GLL, the various taxonomies of strategy, and self-regulatory practices, we, as educators, are in a position to equip our students with the language learning tools necessary so that they can be proactive in taking charge of their learning process in order to achieve their desired results of L2 proficiency within the classroom and beyond.

\section{ACKNOWLEDGEMNTS}

This work was supported by Hankuk University of Foreign Studies Research Fund of 2012

\section{AUTHOR INFORMATION}

Gabriella Torres has been teaching composition, literature and EFL for eight years in the United States and Asia. She is currently an assistant professor of Practical English at Hankuk University of Foreign Studies in Yongin, South Korea. E-mail: gstorres@gmail.com

\section{REFERENCES}

1. Bialystock, E. (1985) 'The compatibility of teaching and learning strategies'. Applied Linguistics 6/3: 255262.

2. Brown, H.D. (2000) Principles of Language Learning and Teaching. $\left(4^{\text {th }}\right.$ edn.) New York: Longman, Pearson Education.

3. Chamot, A.U. (2005) 'Language learning strategy instruction: Current issues and research'. Annual Review of Applied Linguistics 25: 112-130.

4. Chamot, A.U., \& Kupper, L. (1989) 'Learning strategies in foreign language instruction'. Foreign Language Annals 22: 13-24.

5. Chamot, A.U., \& Rubin, J. (1994) 'Comments on Janie Rees-Miller's “A critical appraisal of learner training: Theoretical bases and teaching implications" '. TESOL Quarterly 28: 771-776.

6. Cohen, A.D. (1998) Strategies in Learning and Using a Second Language. Harlow: Longman.

7. Dornyei, Z. (2001) The Psychology of the Language Learner: Individual Differences in Second Language Acquisition. Mahwah, NJ: Lawrence Erlbaum.

8. Ehrman, M.E., Leaver, B.L., and Oxford, R.L. (2003) 'A brief overview of individual differences in second language learning'. System 31: 313-330.

9. Macaro, E. (2001) Learning Strategies in Foreign and Second Language Classrooms. London: Continuum.

10. Naiman, N., Frohlich, M., \& Todesco, A. (1975). 'The good second language learner'. TESL Talk 6: 68-75.

11. Naiman, N., Frohlich, M., \& Stern, H.H. (1978/1996). The Good Language Learner. Clevedon, England: Multilingual Matters. (Original work published in 1978.)

12. Norton, B., \& Toohey, K. (2001) 'Changing perspectives on good language learners'. TESOL Quarterly 35/2: 307-322.

13. Nunan, D. (2002) "Learner strategy training in the classroom: An action research study". In Richards, J. C. \& Renandya, W. A. (Eds.) (2002) Methodology in Language Teaching. Cambridge: Cambridge University Press.

14. O’Malley, J.M., Chamot, A.U., Stewner-Manzanares, G., Russo, R.P., \& Kupper, L. (1985) ‘Learning strategy applications with students of English as a second language'. TESOL Quarterly 19/3: 557-584.

15. O’Malley, J.M., \& Chamot, A.U. (1990) Learning Strategies in Second Language Acquisition. New York: Cambridge University Press.

16. Oxford, R.L. (1990) Language Learning Strategies: What Every Teacher Should Know. New York: Newbury House.

17. Oxford, R.L., Crookall, D., Cohen, A., Lavine, R., Nyikos, M., \& Sutter, W. (1990) 'Strategy training for language learners: Six situational case studies and a training model'. Foreign Language Annals 23/3: 197216. 
18. Oxford, R.L. (2002) "Language learning strategies in a nutshell: Update and ESL suggestions". In

Richards, J. C. \& Renandya, W. A. (Eds.) (2002) Methodology in Language Teaching. Cambridge:

Cambridge University Press.

19. Rubin, J. (1975) 'What the "good language learner" can teach us'. TESOL Quarterly 9: 41-51.

20. Takeuchi, O. (2003) 'What can we learn from good foreign language learners? A qualitative study in the Japanese foreign language context'. System 31: 385-392.

21. Tseng, W.T., Dornyei, Z., \& Schmitt, N. (2006) 'A new approach to assessing strategic learning: The case of self-regulation in vocabulary acquisition'. Applied Linguistics 27/1: 78-102.

22. Vann, R., \& Abraham, R. (1989, April) Strategies of unsuccessful language learners. Paper presented at the annual meeting of Teachers or English to Speakers of Other Languages, San Francisco.

23. Zimmerman, B.J. (2001) "Theories of self-regulated learning and academic achievement: An overview and analysis". In Zimmerman, B.J., \& Schunk, D.H. (Eds.) (2001) Self-Regulated Learning and Academic Achievement: Theoretical Perspectives. Mahwah, NJ: Lawrence Erlbaum. 